\title{
Ulf Brunnbauer, Globalizing Southeastern Europe: Emigrants, America and the State since the Late Nineteenth Century
}

Lexington Books, Lanham, 2016, 357 str.

Ulfa Brunnbauerja slovenskim raziskovalcem migracij najbrž ni treba posebej predstavljati. Zgodovinski antropolog in direktor Inštituta za zgodovino Jugovzhodne in Vzhodne Evrope $v$ Regensburgu je napisal več monografij s področja študij nacionalizmov, analiz sorodstvenih struktur in zgodovine migracij na območju Jugovzhodne Evrope. V svoji najnovejši knjigi, ki je za slovenske raziskovalce zanimiva tako z metodološkega kot vsebinskega stališča, objavlja vpogled v izseljevanje iz Jugovzhodne Evrope od druge polovice 19. stoletja pa do migracijskih tokov v času komunističnih režimov. Po zgledu novejših raziskav ${ }^{1} v$ središče zanimanja postavlja države izselitve in ne priseljenskih držav. S tovrstnim pristopom odpira pahljačo vprašanj, ki tradicionalno niso bila deležna poglobljenega razmisleka.

Jugovzhodna Evropa, meni Brunnbauer, je pravi laboratorij za analizo migracijskih fenomenov. Obsežno izseljevanje iz regije ni bilo deležne tolikšne refleksije kot izseljevanje iz zahodnega dela kontinenta. Brunnbauer meni, da je bilo raziskovanje migracij v Jugovzhodni Evropi tradicionalno omejeno z metodološkim nacionalizmom, osredotočalo pa se je na proučevanje izseljenskih tokov določene nacionalne skupnosti in njenega vključevanja v priselitveno okolje, pri čemer se je proces interpretiralo brez upoštevanja interakcij, v katerih so sodelovali njeni pripadniki. V nasprotju z nacionalno zamejenimi stališči Brunnbauer migracije problematizira v povezavi z oblikovanjem države in nacionalizma. Množične migracije so bile namreč tesno povezane z modernizacijskimi procesi, v katerih je država nastopila kot akter, ki si prizadeva nadzorovati gibanja. Emigracije so ozemeljsko omejeni državi povzročale preglavice, ljudi je država imela za svojo last, tako da je odhajanje prebivalstva pri oblastnikih sprožalo pomisleke. V pričujoči študiji Brunnbauer na primeru Jugovzhodne Evrope analizira, kako je »teritorializirajoča« država poskušala slediti transnacionalnim gibanjem svojega prebivalstva in izvajati svoje pristojnosti na ozemlju, ki ji ni pripadalo. V monografiji se osredotoča prav na ozemlje obeh nekdanjih Jugoslavij in politike, ki sta jih državi izvajali za nadzor nad »svojimi« migranti. Prav zato je knjiga dobrodošla pridobitev za tiste, ki se ukvarjajo z migracijsko preteklostjo na območju današnje Slovenije.

$\checkmark$ uvodu se Brunnbauer pomudi ob klasičnih vprašanjih razlage migracij. Analizo zastavi v okviru integralnega pristopa, ki si prizadeva povezati makro-, mezo- in mikroravni delovanja družbe in odzivanja posameznikov. Migracije so namreč kompleksen, »totalen«, kot sam pravi, družbeni fenomen in zahtevajo tako razumevanje družbene strukture kot delovanja omrežij in posameznih agensov, ki družbena pravila prilagajajo vsakdanji praksi. Pozoren je na posamezne zgodbe in neobičajne

1 Prim. Nancy L. Green in François Veil (2007). Citizenship and Those Who Leave: The Politics of Emigration and Repatriation. Chicago: University of Illinois Press. 
izbire, in selitev predstavlja kot odločitev, povezano z življenjskimi strategijami posameznikov. V uvodu razpravlja tudi o opredelitvah posameznih pojmov, ki so v žarišču razprav raziskovalcev migracij. Problematizira tako vprašanje razmejitve med prostovoljnimi in prisilnimi migracijami kot tudi sam pojem migranta, ki se je v vsakdanji govorici (velikokrat pa tudi v rabi raziskovalcev) uveljavil na podlagi kategorialnega aparata države o klasificiranju gibljivih ljudi. Analitski koncept ne more biti preprosto istoveten državnim opredelitvam, zato Brunnbauer vztraja pri refleksiji človeške mobilnosti in oblikovanju ustreznih znanstvenih opredelitev. Pri razlagi dogajanja si pomaga $z$ interpretativnimi modeli dolgega trajanja, ki onemogočajo, da bi zapadli v poenostavljeno razlago enkratnosti določenega pojava.

Da so migracije kompleksni procesi, ki se ne prekinjajo s spremembo državnih oblik, pokaže že v prvem poglavju, ko razpravlja o razsežnostih čezmorskih migracij z Balkana pred prvo svetovno vojno. Te označuje za logično nadaljevanje sezonskih migracij predindustrijskega časa, s katerimi so se odmaknjene vasi vključile $v$ globalno trgovino. Migracije so sledile migracijam, prepričljivo trdi Brunnbauer, kot dejavnik, ki je gnal k odhodu, niso bile pomembne zgolj okoliščine, temveč transnacionalna omrežja, v katerih so ljudje delovali, in informacije, ki so jih prinašali nekdanji migranti. Interpretacija migracij izključno skozi prizmo ekonomije se zato zdi neustrezna, saj je očitno do razlik prihajalo tudi pri izseljevanju med ekonomsko enako razvitimi regijami. Brunnbauer razliko pojasnjuje $s$ kroženjem informacij in z mrežami, v katerih so bili denimo ljudje ob Jadranskem morju, kjer se je izseljevanje začelo prej, udeleženi pred tistimi na celini. Imeli so sorodnike in znance z migrantskimi izkušnjami, morda so znali italijanski jezik, ki se je zdel uporaben tudi v Ameriki, tako da so se med njimi selitvene poti čez lužo lahko prej oblikovale.

Omrežja so igrala pomembno vlogo tudi ob rekrutaciji delavcev za ameriški trg. Eden bolj zloglasnih sistemov, ki je deloval prek sorodniških in klientelnih podpornih mrež, je bil v Združenih državah znan pod imenom padrone in je bil sprva razširjen med italijanskimi migranti. Pozneje se je uveljavil med grškimi priseljenci in je bil po ugotovitvah Dillinghamove priseljenske komisije vzpostavljen $v$ vsakem malo večjem ameriškem mestu. Grški poslovneži v ZDA so na ta način iz Grčije za čiščenje čevljev in prodajo sadja in zelenjave novačili mlajše fante, predvsem iz province Arkadija, kjer so že opravljali podobna dela. Mladeniči so delali v neizprosnih razmerah pod budnim očesom padrones, kot ceneni delovni sili pa jim je uspelo izriniti italijansko konkurenco. Velikokrat so jih šefi prisilili, da so domov pisali pisma, v katerih so opevali lepoto svojega življenja v ZDA in tako privabljali nove delovne roke.

Opisu gospodarskega »uspeha« migrantov sledi prikaz njihovega društvenega in družbenega organiziranja, nato pa krajša razprava o vračanju migrantov pred prvo svetovno vojno. Večina tistih, ki so se v ZDA priselili pred prvo svetovno vojno, ni razmišljala o stalni naselitvi, sklene Brunnbauer. Veliko jih je odločitev pozneje tudi spremenilo, vendar je že sama želja po vrnitvi vplivala na organiziranje njihovega življenja v ZDA. Tesni stiki z domačimi so vplivali na obe plati procesa, izseljenci so se čutili del domače skupnosti, domov so pošiljali denar, da bi lahko domači živeli 
lagodnejše življenje, in upali, da bodo nekoč spet sprejeti v domači krog. Vračanje je podžgalo čar Amerike in tako tlakovalo pot nadaljnji migraciji. Izseljenci so s pošiljkami denarja odločilno pomagali tudi lokalni ekonomiji, tako da so lahko domači končno odplačali dolgove, prenovili hiše in nakupili kmetijsko mehanizacijo. Na neki način so bili torej ekonomski učinki čezmorskih migracij podobni tistim, ki so jih v šestdesetih letih prinesli gastarbeiterji, ugotavlja Brunnbauer.

$\checkmark$ prvem poglavju avtor nameni pozornost tudi preglavicam, ki jih povzroča vprašanje kvantifikacije selitev. Težave bržkone povzroča že to, da ni jasno, kdo je bil opredeljen za migranta, države niso vodile natančne statistike odhodov (Cislajtanska državna polovica Avstro-Ogrske), posamezniki so se večkrat selili med državi odhoda in prihoda, pa tudi ameriška statistika ni bila zanesljiva, saj je v en koš metala »Bošnjake, Dalmatince in Hercegovce«, v drugi pa »Bolgare, Srbe in Črnogorce«.

Vprašanja, kako je država posegala $v$ nadzor migracijskih tokov in kako je bila tovrstna regulacija povezana s procesi modernizacije in oblikovanja nacije, Brunnbauer postavlja v čas pred prvo svetovno vojno. Medtem ko Cislajtanija vse do svojega konca ni uspela uvesti kontrole nad izseljevanjem (le ob izbruhu vojne je veljala prepoved za tiste, ki niso opravili vojaške služnosti), pa so v ogrski državni polovici deset let pred prvo svetovno vojno že sprejeli natančne ukrepe, s katerimi bi nadzorovali odhode tistih, ki so si želeli »kontinuirano življenje na tujem«, kot je zakonodaja definirala emigrante. Država je začela kontinuirano posegati v migracijsko politiko šele po prvi svetovni vojni. Čeprav nadzor nad odhajanjem in prihajanjem ni bil glavna preokupacija oblasti Kraljevine Srbov, Hrvatov in Slovencev oz. Kraljevine Jugoslavije, pa so bili mehanizmi regulacije migracij med pomembnimi vzvodi nacionalizacije državljanov. Kraljevina si je torej po oblikovanju države prizadevala homogenizirati južnoslovanske narode oz. konstitutivna plemena, kot se je glasila uradna dikcija, v enotno jugoslovansko nacijo, $v$ kateri ni bilo prostora za etnične manjšine. Korak v tej smeri je bila nacionalizacija migracije po vzoru Italije, kot ugotavlja Brunnbauer, pa najbrž še bolj po zgledu Ogrske, od katere je Kraljevina navsezadnje prevzela dobršen del uradništva. Izseljevanje je bilo s tega stališča ocenjeno kot škoda za »narodno telo«, ki je tako izgubljalo vitalni del svojih pripadnikov.

Po drugi strani pa je država v obsežni emigrantski populaciji, ki je sicer izhajala z ozemlja Kraljevine, a je bila na tujem še pred vzpostavitvijo države, videla možnost za izvrševanje svoje politike in poveličevanje jugoslovanske nacije, katere del naj bi bili izseljenci. Niso bili izseljenci sami tisti, ki so oblikovali odnos do »domovine«, torej Kraljevine SHS, temveč je ta prek organizacij in konzularnih služb oblikovala diasporo $v$ duhu integralnega jugoslovanstva. Jugoslovani na tujem so $v$ uradnem diskurzu postali znani kot »deseta banovina«, kar je jasen znak, da je država koncipirala suverenost prek teritorialnih meja. Prizadevanje za oblikovanje lojalne diaspore niti ni bilo prikrito. Že podnaslov glasila, namenjenega izseljencem, Iseljenički svet, Časopis za nacionalnu i kulturnu propagandu u jugoslovenskoj emigraciji je odkrito naslavljal »jugoslovansko emigracijo« in govoril o propagandi med njenimi člani. Za potrebe konstruiranja zamišljene jugoslovanske skupnosti med emigranti je 
država vzpostavila tudi Zvezo organizacij izseljencev (Savez organizacija iseljenika) in Izseljenski muzej v Zagrebu, ki sta poudarjala jugoslovansko noto izseljencev. Uspeh oblikovanja lojalne diaspore je bil sicer pičel. Eden od razlogov je bil tudi v tem, da je država ob preprečevanju izseljevanja nacionalnih elementov krepila odhode etničnih manjšin, torej Nemcev, še bolj pa Madžarov in neslovanskih muslimanov, in tako nehote formirala sovražne izseljence.

V sklepnem poglavju Brunnbauer prikaže izseljensko politiko socialističnega režima druge Jugoslavije do liberalizacije $v$ šestdesetih letih, ko so ekonomske težave prisilile državo, da je sprostila meje, ki so jih iskalci dela ilegalno sicer prestopali že prej. Fenomen gastarbeiterjev je še vedno premalo raziskan, poudarja Brunnbauer. $Z$ delavci na tujem se v monografiji ne ukvarja, poskuša pa nakazati povezanost pojava s preteklimi delavskimi migracijami v regiji in učinki denarnih pošiljk na domačo ekonomijo. V selitveni politiki socialistične Jugoslavije prav tako opaža več kontinuitet kot ostrih rezov z režimom monarhije. Ravno tako kot Kraljevina je tudi socialistična Jugoslavija skušala oblikovati lojalno diasporo, le da je izhajala iz drugačnih premis. $V$ tem primeru je bila temeljna ločnica politična opredelitev izseljencev, tako da je država ločevala med staro migracijo, ki se je izselila pred drugo svetovno vojno in je bila vdana režimu, in antikomunistično, ki je veljala za sovražno. Zveste izseljence je država skušala omrežiti s pomočjo matic, izseljenskih združenj, ki pa so bila organizirana po republiškem ključu (tako je nastala tudi Slovenska izseljenska matica) in so med izseljenci skrbela za promocijo etnično utemeljene nacionalne identitete (sicer uokvirjene v jugoslovansko državo). Podeljevanje štipendij izseljencem in njihovim potomcem, gostovanje folklornih skupin in finančna podpore lojalnim društvom so bili instrumenti, prek katerih je država želela izseljence vključiti v svoje okrilje. Moč socialističnega gospodarstva pa je država želela izkazati tako, da je staro migracijo spodbujala k vrnitvi v domovino. $V$ vsa glavna izseljenska središča je že kmalu po vojni poslala ladji Partizanka in Radnik, ki naj bi domov pripeljali mlade, aktivne ljudi, željne graditi socialistično gospodarstvo. Upi so se kmalu razblinili, saj so domov velikokrat prišli stari in nebogljeni, mnogi pa so se ob pomanjkanju v Jugoslaviji odločili za ponoven odhod v državo, ki so jo zapustili. Odločitev o primernosti za vrnitev je bila bolj odvisna od etnične pripadnosti kot pa od državljanstva, kar dokazuje tudi primer Jožefa Gulina iz Nove Gorice, ki se je pred fašističnim preganjanjem umaknil v Perzijo, Jugoslavija pa mu je - na prošnjo žene, ki je ostala doma - dovolila povratek, kljub temu da je bil državljan Italije.

Brunnbauer v celotni knjigi prepleta strategije posameznikov s politikami držav in pokaže, kako politike nadzora nikoli niso uspele uresničiti svojega namena, saj so migranti vselej iznašli strategije, s katerimi so zaobšli regulatorne mehanizme. Želja po izvajanju suverenosti prek meja držav, torej njihova transteritorialnost, je seveda spremljala modernizacijo, a se je razvila prav zaradi prisotnosti pripadnikov zamišljene skupnosti, ljudi, ki jih je imela država za svojo last, v prekooceanskih deželah. $\mathrm{Na}$ ta način je država oblikovala diasporo kot integralni del etnonacionalnega telesa. Diaspora v tem smislu ni analitski koncept, s pomočjo katerega bi lahko proučevali 
pojave, temveč čista državnobirokratska kategorija, ki se spreminja glede na politiko držav. Žal je treba dodati, da so bile raziskave migracijskih gibanj v državah Jugovzhodne Evrope velikokrat del državnih prizadevanj po nation builduingu, tako da so bili domnevno analitski koncepti dejansko odsev državne ideologije. Ker je Brunnbauerjeva monografija dobrodošel odmik od tovrstnega metodološkega nacionalizma, upam, da jo bodo, čeprav se slovenskega prostora žal dotakne le bežno, bralci dobro sprejeli.

Miha Zobec 